\title{
PRoCEsso CRIATIVO E APRECIAÇÃO ESTÉTICA NO GRAFISMO WAUJA
}

\author{
Aristóteles Barcelos Neto*
}

resumo: A idéia de que a criação artística tem sua origem em mundos nãohumanos é um tema bastante difundido na etnologia das terras baixas da América do Sul (Taylor, 2003; Viveiros de Castro, 1986). Este artigo oferece uma visão a respeito do assunto estendendo sua descrição a uma análise do lugar social da beleza e da fealdade na arte gráfica dos Índios Wauja do Alto Xingu. Argumenta-se que a paisagem estética wauja está emoldurada por idéias de excelência e perfeição que devem atingir plenitude nos grandes rituais feitos em nome de indivíduos de alto status sociopolítico.

palavras-chave: grafismo indígena da Amazônia, noções nativas de criatividade e estética, objetos para pagamento ritual. abstract: The idea that artistic creation comes from non-human worlds is a very present theme in the lowland South America ethnology (Taylor, 2003; Viveiros de Castro, 1986). This article offers a vision about this subject expanding its description to an analysis of the social place of beauty and ugliness in the graphic art of the Wauja Indians of the Upper Xingu river. I argue that the wauja aesthetic paysage is framed by ideas of excellence and perfection which must achieve fullness in the great rituals performed for high rank individuals.

key words: amazonian graphic art, native notions of creativity and aesthetics, artifacts for ritual payment.

\section{Introdução $^{1}$}

* Pós-doutorando no Departamento de Antropologia da Universidade de São Paulo.

1 Agradeço à FAPESP, à CAPES, ao FUNPESQUISA/ UFSC, ao CADCT/Governo do Estado da Bahia e ao Museu Nacional de Etnologia os apoios concedidos para a realização dos trabalhos de campo e das análises dos dados. Sou também grato aos Wauja, especialmente a Atamai, Kamo, Aulahu, Kalupuku, Yejoku e Katsiparu. Lux Vidal, Maria Rosário Borges, Pedro Agostinho da Silva, Rafael de Menezes Bastos, Bruna Franchetto, Michael Heckenberger, Carlos Fausto e Fabíola Silva contribuíram com valiosos comentários e incentivos à minha pesquisa entre os Wauja.

A criação, circulação e apreciação de desenhos entre os Wauja são experiências que lançam desafios descritivos e analíticos ainda pouco comuns na etnologia da Amazônia, a começar pelos horizontes de reflexão sócio-cosmológica abertos pelo estudo do grafismo. O campo das artes gráficas wauja é extremamente profícuo, sendo muitos os seus suportes de expressão - seres humanos, animais, monstros,

\section{artigos}


"roupas" de seres "sobrenaturais" e várias classes de artefatos -, isso sem contar também a dimensão "imaterial" e criativa das artes visuais na vida onírica.

Este artigo explicita dois momentos distintos e complementares de um continuum produtivo: a criação e a apreciação estética do grafismo pelos Wauja. O discurso sobre a criatividade artística a aponta como um domínio basicamente não-humano. A agência específica dos Wauja é materializar esse conhecimento criativo não-humano através de técnicas muito precisas e meticulosas. A capacidade de processar tal conhecimento através de perfeitas resoluções plásticas e técnicas é o que os Wauja vêem como seu domínio particular no universo de expressão visual constituído pelos suportes mencionados acima. No interior do mundo wauja, o material artístico não-humano é renovado por uma estética rigorosamente cultivada sob as éticas do respeito, da vergonha e da generosidade e sob o desejo da perfeição, a qual é reservada primordialmente para as ocasiões mais importantes da vida comunitária: os grandes rituais voltados para a chefia e para as alteridades nãohumanas mais poderosas, especialmente "representadas" por flautas, clarinetes e máscaras.

Os Wauja ${ }^{2}$ são um povo de língua arawak que habita as proximidades da margem direita do baixo rio Batovi, na região ocidental da bacia dos formadores

2 O leitor encontrará na literatura xinguana o termo "Waurá", que é o etnônimo difundido desde Karl von den Steinen (1886 e 1894). Optei por grafar "Wauja" por este ser o etnônimo auto-atribuído. Os Wauja somam uma população de aproximadamente 360 pessoas, das quais 312 (dados censitários de outubro de 2004) residem em uma única aldeia circular com o sistema de praça central e casa das flautas. do rio Xingu, Estado do Mato Grosso, Brasil. No entanto, a história dos Wauja no Alto Xingu é bem mais antiga. Pesquisas arqueológicas recentes apontam a chegada dos ancestrais dos Wauja à região por volta do século IX d.C. (Heckenberger, 2001). Ao que indicam os estudos etno-históricos mais recentes (Franchetto \& Heckenberger, 2001) teve início, supostamente em meados do século XVIII, a formação de uma sociedade regional multiétnica, marcada por um ethos comum, a qual integra, além dos Wauja, outros nove grupos de diferentes filiações lingüísticas - Kuikuro, Kalapalo, Matipu e Nahukwá (Carib), Kamayurá e Aweti (Tupi) e Trumai (de língua isolada).

O grafismo dos povos do Alto Xingu foi inicialmente descrito por Karl von den Steinen no seu clássico Entre os aborígenes do Brasil Central (1940 [1894]). Mais de um século depois de tal extraordinária inauguração etnográfica, o grafismo xinguano continua sendo um assunto pouco conhecido, apesar das descrições parciais sobre quatro dos dez grupos da região ${ }^{3}$. No conjunto da obra etnológica sobre as sociedades indígenas das terras baixas da América do Sul, o trabalho de Lévi-Strauss sobre a pintura facial Kadiwéu (1955) é o primeiro a apresentar, de modo decisivo, alguns dos desafios teóricos que os sistemas gráficos dessas sociedades lançam à antropologia. Esse estudo é o marco inaugural de uma linha de pesquisa em etnologia amazônica que começou a tomar visibilidade sobretudo a partir da década de 1980 com a incorporação das reflexões teóricas sobre

3 Agostinho (1974); Gregor (1982); Coelho (1981 e 1993); Fénelon Costa (1988); Ribeiro (1993) e Monod-Becquelin (1993). 
as cosmologias e as noções de corpo, alma e pessoa ${ }^{4}$.

\section{I - Criatividades não-humanas}

O que aqui chamamos de grafismo é para os Wauja um gigantesco universo de expressões visuais sem fronteiras espaçotemporais claramente definidas. O yanaiki (termo que também inclui as cores) surgiu no tempo em que os animais eram "gente" e falavam, isto é, quando seus aspectos anatômicos eram unicamente antropomorfos ou zooantropomorfos e quando eles estabeleciam comunicação direta com os humanos. Porém, uma mudança cósmica fez com que esses antigos "animais", denominados yerupoho, deixassem de ser exclusivamente "gente". O aparecimento do sol colocou em curso processos de transformação dos seres existentes (com exceção dos humanos) e de criação de novas formas de vida, pelo menos quanto aos seus aspectos etológicos e anatômicos exteriores. Seres com as mais diferentes morfologias apareceram em todos os espaços do cosmo wauja: surgiam os apapaatai $i^{5}$ entidades xamânicas que estão na origem tanto da doença quanto da cura (Barcelos Neto, 2004).

4 Vide por exemplo as contribuições de Gow (1988 e 1999); Guss (1989); Lagrou (1998); Reichel-Dolmatoff (1978); Seeger et alli (1979); Seeger (1981); Velthem (2003); Viveiros de Castro (1979 e 1986) e a coletânea de artigos em Vidal (1992 org.).

5 A noção de apapaatai está muito além dessa referência ontogênica contida no mito do surgimento do sol. Não há espaço aqui para analisá-la. De modo sumário, podemos dizer que os apapaatai estão compreendidos por uma escala de transformações ontológicas múltiplas e desiguais que os apreende como animais, monstros, artefatos, "espíritos", "heróis culturais", e/ou xamãs; essa mesma escala, em sua amplitude máxima, inclui, contextualmente, os próprios Wauja. Para uma leitura aprofundada da noção de apapaatai vide Barcelos Neto (2004) e Viveiros de Castro (2002).
Essas novas formas de vida correspondem, em sua maioria, às milhares de "roupas" que os yerupoho inventaram para se proteger dos efeitos deletérios do sol. Ao vesti-las, grande parte deles transformou-se em muitas das espécies animais hoje conhecidas. Há ainda "roupas" de yerupoho de natureza monstruosa. Neste caso, elas recebem a simples denominação de apapaatai. Contudo, essas "roupas" (máscaras) não são uma exclusividade dos apapaatai; os Wauja também as fabricam, porém ritualmente, com o objetivo de superar um estado patológico grave provocado pelos apapaatai.

O yanaiki foi o dispositivo básico que permitiu a singularização de cada espécie animal e que impediu o caos ontológico que teria irrompido com o surgimento do sol, pois o seu calor era capaz de fixar de maneira irreversível e indistinta os corpos dos yerupobo que não tivessem a proteção das "roupas". Se nenhuma espécie animal é igual à outra é porque cada "roupa" foi anatomicamente desenhada/trançada de acordo com as capacidades criativas e expressivas de cada yerupoho individualizado. A arte, a vida e, conseqüentemente, a ordenação morfológica e etológica dos seres não-humanos surgiram, em grande parte, do labor meticuloso e personalizado representado pelas "roupas". Portanto, a maioria dos animais e monstros é resultado da agência específica de seres antropomorfos (yerupoho) dotados, segundo os Wauja, de prodigiosa inteligência e criatividade artística.

As exegeses sobre a mito-cosmologia dizem que o repertório dos motivos gráficos atuais foram majoritária e lentamente transmitidos aos Wauja, pelos apapaatai, através dos sonhos e transes dos 


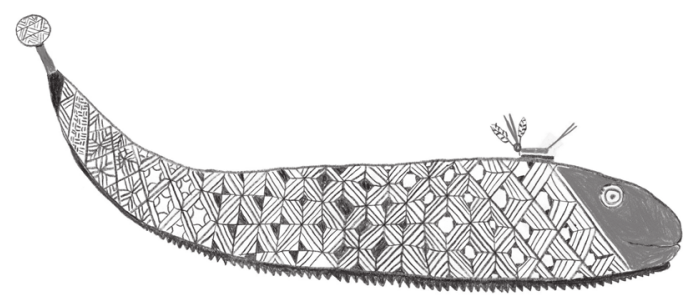

Figura 1 - Arakuni. Autor: Aulahu Wauja, 2000.

doentes e dos xamãs. Os desenhos, imagens oníricas dos tempos imemoriais, são uma dádiva dos contatos, em primeira instância maléficos, entre humanos e apapaatai. Os adoecimentos graves e seus processos de cura, estes últimos com abundante uso do tabaco como psicoativo, são os elos primordiais desse tipo de contato. O ritual, situação em que os desenhos surgem em enorme profusão e variedade, é o principal elo criativo e produtivo desses contatos. No ritual, o conhecimento iconográfico é reafirmado e colocado em movimento como em seu contexto original, quando as "roupas" animalescas e monstruosas foram confeccionadas e se puseram a dançar em torno e sob o comando de um trio de flautas de madeira conhecidas como Kawoká. Todos os rituais wauja, com menor ênfase para aqueles de caráter funerário e pós-funerário, estão intensamente focados sobre as alteridades não-humanas (apapaatai e yerupobo).

Além dos desenhos e cores inventados pelos yerupoho, existe um outro conjunto de motivos gráficos - dentre o qual figura o motivo mais importante para os Wauja, denominado kulupiene e difundido na literatura como merechu (Steinen, 1940) - que foi inventado pelo personagem mítico Arakuni (Figura 1) ${ }^{6}$.

6 Vide Barcelos Neto (2000 e 2002) para uma versão completa desse mito.

\section{II - O repertório gráfico e o discurso da criatividade}

Os motivos gráficos reconhecidos pelos Wauja expressam-se em quatro tipos de suporte: 1. no corpo dos animais, 2. no corpo dos humanos (leia-se xinguanos, pois só eles sabem fazer yanaiki corretamente) ${ }^{7}$, 3. no dos yerupoho e apapaatai e 4. na cultura material.

A arte gráfica wauja não possui nenhuma relação semântica direta com o grafismo dos animais. Este último é um sistema fechado e fixo - os desenhos da pele das onças jamais migrariam para a plumagem das araras azuis e vice-versa; tanto uma quanto a outra são "roupas" de formatos e padrões fixos -, enquanto o grafismo wauja é um sistema de fronteiras abertas e moventes, como a própria sociedade xinguana (Menget, 1993 e Menezes Bastos, 1995). Entretanto, tal abertura e tal movimento ocorrem fundamentalmente em direção às alteridades monstruosas (apapaatai), que conferem à arte wauja sua natureza transformativa.

Todo o sistema gráfico wauja está estruturado a partir da combinação de cinco formas visuais: 1. triângulos (retângulos e isósceles), 2. pontos, 3 . círculos, 4. quadriláteros (losangos, quadrados, retângulos e trapézios) e 5 . linhas (retas e curvas), que são os elementos gráficos mínimos dessa arte. Como em qualquer sistema de arte ornamental, são as combinações precisas dos elementos mínimos que determinam a formação de um motivo. O grafismo

7 Devido à sua complexidade formal e conceitual, a pintura corporal wauja merece um artigo à parte. Aqui, faço apenas as menções estritamente necessárias para elucidar processos nos quais as pinturas do corpo e dos artefatos possuem uma proximidade analítica.

cadernos de campo - n. 12 - 2004 
Quadro I: Motivos gráficos criados pelo personagem mítico Arakuni
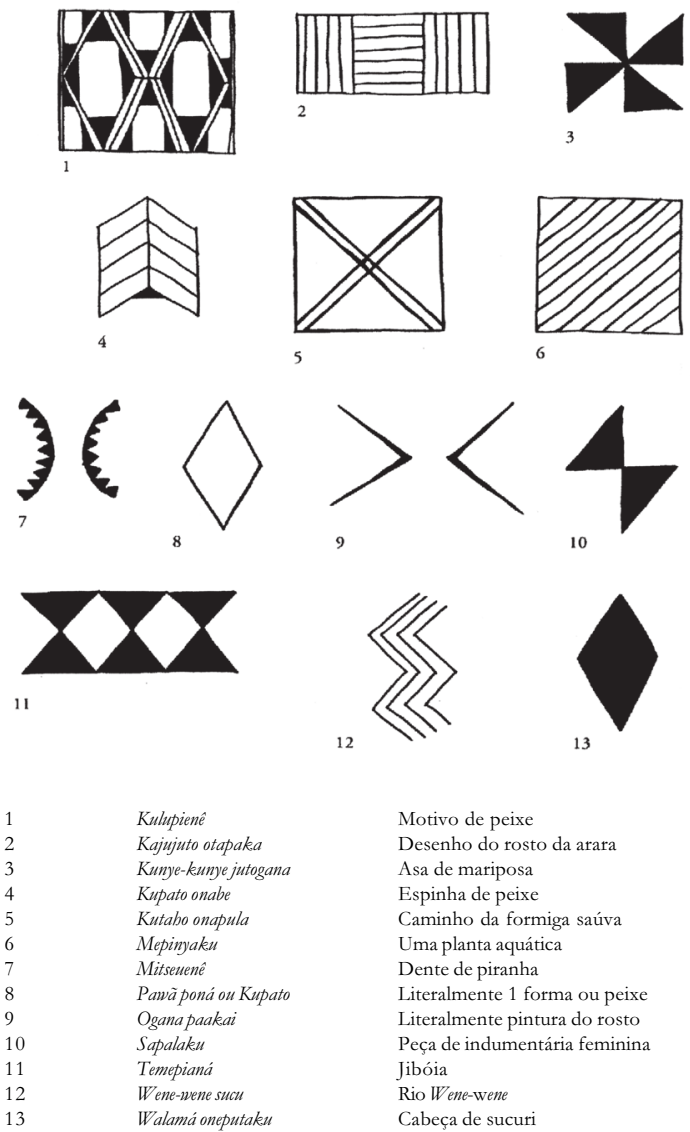

wauja utiliza um repertório de 40 a 45 motivos fixos na ornamentação da cultura material. Há ainda um repertório flutuante de variações de motívicas que é resgatado em situações de maior liberdade expressiva. Apesar desse extenso repertório, apenas dezesseis motivos gráficos são empregados com freqüência. Dentre esses, o motivo kulupiene tem sido desenhado com altíssima freqüência sobre todos os tipos de suportes desde a primeira notícia histórica sobre os

8 Vide em Barcelos Neto (2001) as implicações históricas da manutenção e ênfase produtiva sobre dois diferentes conjuntos de repertórios gráficos xinguanos xinguanos, em $1884^{8}$. Segundo os Wauja, esses dezesseis motivos são "muito antigos", treze (ou catorze, a depender da versão) deles foram inventados pelo personagem mítico Arakuni para recobrir a sua "roupa"-cobra (Quadro I) ${ }^{9}$. Enquanto Arakuni trançava a sua "vestimenta" com fibras de taquarinha, ele simultaneamente criava as músicas que mais tarde vieram a ser cantadas no ritual pós-funerário Kaumai (ou Kwarip, na língua kamayurá).

O sistema visual wauja possui uma especial abertura para a interpretação plástica, seja de seus temas tradicionais ou de temas estrangeiros ${ }^{10}$. Ao longo do tempo ${ }^{11}$, esse fenômeno é responsável por um aumento/ renovação dos repertórios gráfico e tridimensional. No entanto, na mesma medida em que se observa um movimento em direção ao acúmulo de motivos, constatase um movimento inverso. Ou seja, o repertório torna-se tão extenso que muitos motivos são "esquecidos" (ocultados), mas podem ser posteriormente recuperados.

9 Esclareço que os motivos de Arakuni fazem parte de um amplo sistema visual, sobre o qual as possibilidades de análise extrapolam os limites deste artigo. O leitor encontrará em Barcelos Neto (2002 e 2004) abordagens complementares a estas.

$10 \mathrm{O}$ grafismo wauja incorpora, temporariamente e em contextos restritos, letras do alfabeto latino, algarismos e alguns emblemas e insígnias da sociedade nacional o motivo do avião Bandeirante, a bandeira do Brasil, os distintivos da FAB, a logomarca dos filmes Agfa, e o emblema do São Paulo Futebol Clube - como motivos gráficos. Conforme Coelho (1993: 624), a "maioria dessas inovações não são escolhidas ao acaso, e sim devido à semelhança entre seus elementos e a arte alto-xinguana".

11 Para esta análise em particular trabalhei com unidades sincrônicas de dez anos em uma profundidade diacrônica de um século.

\section{artigos}


Citarei alguns exemplos desse processo, que está apenas parcialmente descrito, começando por uma observação de Vera Coelho a propósito de Tawapo ${ }^{12}$, ceramista wauja conhecedor de um grande repertório de motivos de representações animais:

[ele] sempre demonstrou interesse muito vivo em ampliar os limites desse repertório. Assim sendo, na ocasião de minha partida pediu-me que lhe desse de presente algumas fotografias de vasilhas pertencentes a coleções de museus. Acedi ao pedido, mas sugeri que fizesse uma seleção das que mais the agradavam, pois não poderia fornecer a coleção completa. Surpreendentemente, a escolha recaiu sobre cinco vasilhas zoomorfas entre as quais apenas uma não constava de seu repertório. Acredito que seu interesse não era tanto pelo repertório como pela maneira de representar os animais. Os escolhidos foram os seguintes: Coleção von den Steinen VB 2974 (carrapato), VB 2999 (morcego); Coleção Schultz: RG 11608 (mutum), RG 11630 (mutum), RG 11600 (macaco) (Coelho, 1981: 72-73).

O interesse de Tawapo pelas duas panelas mutum e pela panela carrapato reflete dois aspectos importantes da dinâmica da arte wauja: a variação interpretativa sobre um mesmo motivo e a renovação temática. No entanto, para nossa discussão, a escolha do inseto é mais significativa. Representações de insetos na cerâmica wauja são quase sempre inusitadas e despertam muita

12 “Tauapã” na grafia de Coelho (1981). curiosidade e divertimento, dois aspectos relevantes para os padrões wauja de aceitabilidade e agradabilidade estéticas.

A cerâmica wauja corresponde a mais elaborada classe de artefatos do sistema de objetos do Alto Xingu. Seus tipos variam desde minúsculas panelinhas que cabem na palma da mão até enormes panelas de 115 centímetros de diâmetro ${ }^{13}$. Quando destinadas aos rituais, as panelas são recobertas com pinturas cuidadosas e refinadas que afirmam a eficácia estética que esses objetos devem ter em tais contextos. As elaboradas formas tridimensionais e as originais interpretações individuais nas panelas zoomorfas suscitam especial interesse estético entre os Wauja. Por várias vezes pude observar crianças e adolescentes contemplando esses objetos e explorando táctil e visualmente os detalhes anatômicos dos animais modelados na argila. Esse aspecto lúdicoestético ligado às panelas zoomorfas não está presente apenas na infância dos indivíduos; um wauja de idade madura, ao saber que eu tinha encomendado uma panela-carrapato para a coleção do Museu de Arqueologia e Etnologia da Bahia, resolveu encomendar uma para ele também, simplesmente porque achou bonita e engraçada uma panela modelada com a forma desse inseto.

Os exemplos de Tawapo e da encomenda do senhor wauja demonstram simultaneamente a descontinuidade temporal do repertório e o interesse em efetuar resgates sobre ele. A panela carrapato coletada por Karl von den Steinen em 1887 caiu em um fosso de esquecimento, mas ela continua absolutamente original, mais

13 Vide ensaio fotográfico sobre a cerâmica wauja na seção Artes da Vida desta edição.

cadernos de campo $\cdot$ n. $12 \cdot 2004$ 
Quadro II: Variações formais do motivo kulupiene
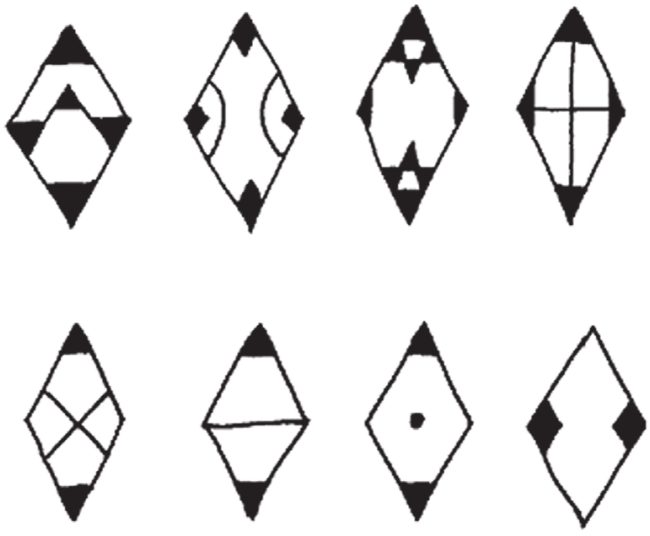

de um século depois, exatamente porque não se esqueceu o mais importante: a "alegria" que artefatos desse tipo podem despertar. A minha experiência em campo sugere que esses fossos de esquecimento parecem ter profundidades muito menores do que se tem imaginado, o que aponta o problema da análise para outra direção, sendo então mais adequado falar de ocultamento do que de esquecimento ${ }^{14}$.

Os conceitos inerentes aos temas são dificilmente esquecidos. A comicidade do tema "panela-carrapato" seguramente sobreviveu nas representações de tantos outros insetos que os Wauja gostam de modelar: besouros, abelhas, gafanhotos, formigas, etc.

Assim como as formas de expressão tridimensional, o grafismo também está incluído nos movimentos mais amplos de ocultamento, interpretação e renovação motívicas. No caso do Alto Xingu, esses

14 Equívocos históricos dessa natureza podem ser facilmente cometidos por estudiosos de coleções de museus e museólogos que limitam suas análises ao que já é empiricamente muito limitado, o repertório em si, e que desconhecem o universo conceitual específico dos artefatos que selecionaram para seu estudo. Em face às atuais condições e qualidade da documentação das coleções etnográficas de museus brasileiros, duvido que os estudos de coleções possam avançar sem novas pesquisas de campo especialmente voltadas para elucidar os problemas oriundos da própria natureza das coletas e para compreender a dinâmica dos artefatos em seus respectivos sistemas tecnológicos e artísticos. movimentos são em grande parte devedores das redes rituais que integram todas as artes (música, dança, ornamentação corporal e artefatos) e as fazem circular.

Ao analisar artefatos de coleções xinguanas produzidos entre 1940 e 1998, registrei 23 variações interpretativas do motivo kulupiene (vide oito exemplos no Quadro II) e três possibilidades composicionais desse motivo, cada uma variando de acordo com os tipos de simetria e ritmo. Mas o que tais variações significam para os Wauja? Segundo eles, elas são ditas surgir através dos contatos oníricos dos xamãs visionários-divinatórios (denominados yakapá) e dos doentes graves com os apapaatai. Variações como as exemplificadas no Quadro II teriam sido vistas nas "roupas" ou no corpo dos apapaatai que atacaram o doente.

Quadro III: Exemplos de Motivos Gráficos

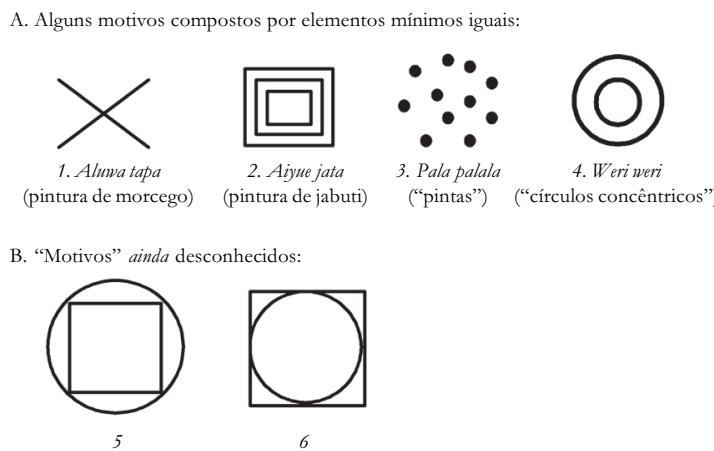

Durante o levantamento de motivos e padrões compositivos do grafismo wauja em 1998, pedi a um dos meus informantes que identificasse e comentasse algumas formas geométricas. Perguntei se as combinações de formas ("motivos") de números 5 e 6 do Quadro III eram conhecidas. Supus que sim, por serem compostas por elementos mínimos bastante difundidos (círculo e quadrado) e devido ao uso de um princípio fundamental

artigos 
da composição gráfica wauja, a circunscrição. A resposta do informante foi para mim uma surpresa. Ele não apenas disse que os "motivos" 5 e 6 do Quadro III eram desconhecidos pelos Wauja, mas acrescentou que é possível que os apapaatai os inventem, ou que já os tenham inventado, e que os yakapá talvez um dia os descubram, podendo assim transmitir o conhecimento desses "motivos" aos Wauja. O informante acrescentou que só dessa maneira, através da visão poderosa de um yakapá, ele poderia me dizer se aqueles motivos existem de fato. Esse grafismo oculto do sonho e do transe nada difere do grafismo constantemente em evidência nas panelas, cestos e corpos desde tempos imemoriais. De fato, eles só estão separados pela temporária barreira da materialização física. Os yakapá conhecem muitos desenhos que jamais foram reproduzidos ou vistos pelos demais membros de sua comunidade. Esse grafismo oculto está guardado na memória dos seus sonhos e transes.

Em vários momentos da pesquisa de campo pude observar as extensões empíricas da idéia wauja de que o universo criativo dos apapaatai é transferido para os domínios humanos através dos yakapá. Essas dádivas artísticas dos apapaatai, quando interpretadas e exibidas, tornamse patrimônio coletivo. Assim, todas as pessoas podem fazer uso dos motivos e elaborar seus desenhos de acordo com as preferências compositivas vigentes entre os Wauja.

Alguns meses antes da minha primeira temporada em campo (abril e maio de 1998), Kamo, um eminente yakapá, sonhou com um apapaatai cuja "roupa" estava repleta de um motivo que ele considerou "muito bonito". Ele resolveu então reproduzi-lo num cesto cargueiro trançado com fibras de buriti. Segundo Kamo, a novidade foi apreciada e mais cestos foram feitos com esse mesmo motivo por outras pessoas. O motivo foi identificado como sendo kajujuto otapaka ("pintura do rosto da arara"). À primeira vista, pereceu-me difícil reconhecê-lo enquanto kajujuto otapaka. Mas, depois de analisá-lo mais detidamente, percebi que se tratava de uma variante formal do referido motivo. A composição de Kamo era uma simplificação da tradicional representação do kajujuto otapaka: ao invés de três linhas paralelas e três linhas perpendiculares àquelas, Kamo desenhou (trançou) apenas três linhas paralelas emolduradas por um quadrado. Uma variação plástica nesse nível é considerada uma novidade resultante de contatos com os apapaatai. No entanto, a mesma não permanece por muito tempo no circuito produtivo, pois ela sofre um desaparecimento virtual, sendo logo substituída por outras variações, elas próprias o resultado de um movimento conceitual para o exterior, ou seja, para as alteridades não-humanas. A memória sobre as variações formais é vaga e os Wauja raramente se lembram dos nomes das pessoas que "primeiramente" fizeram os desenhos "novos". Aos Wauja, o que importa não é se os motivos ou padrões de composição são exatamente novos, e sim a sua permanente circulação, esta apontando para dois processos cognitivos básicos da arte wauja: "esquecer" e reinventar.

Considero tais variações como partes de um conjunto oculto de motivos que podem emergir de acordo com preferências idiossincráticas, as quais, em sua maioria, 
resultam de experimentações formais sobre o próprio sistema gráfico. Esse interesse exploratório produz o referido repertório de variantes. Sua base produtiva é constituída por um conjunto fixo de motivos que, à primeira vista, corresponde aos motivos inventados por Arakuni.

Como bons artistas gráficos, os Wauja também fazem as suas próprias análises, que foram apresentadas a mim tanto através dos mitos quanto das imagens de suas personagens. Ao associar cuidadosamente as duas análises, pude notar que a "roupa"cobra de Arakuni é a matriz de todo o sistema gráfico. Para chegar a essa conclusão foi necessário coletar dezenas de desenhos e submetê-los aos comentários nativos. De desenho em desenho, a relação que os Wauja faziam entre a amplitude total de seu repertório gráfico e a "roupa"-cobra de Arakuni era esclarecida. Apontando para as representações visuais altamente estandardizadas dessa "roupa", os melhores conhecedores das artes do desenho e do mito diziam: "todos os desenhos estão aqui". Para os Wauja, Arakuni inventou o essencial. Os que o sucedem reinventam a sua arte em uma multiplicidade de variações formais.

Em suma, os principais motivos gráficos têm sua origem em Arakuni, mas a sua intensa circulação entre diferentes mundos produz novidades que são conceituadas em termos da idiossincrasia e criatividade dos apapaatai. Assim, de acordo com as explicações wauja, os desenhos circulam num sistema bipolar entre humanos e apapaatai, e a passagem de um pólo ao outro é feito através dos adoecimentos graves, do xamanismo e dos rituais de cura (Barcelos Neto, 2004).

\section{III - Padrões estético-formais do} grafismo

Em qualquer expressão artística, o domínio dos processos técnicos é a condição essencial para a produção de uma obra. Mais do que isso: o domínio das técnicas influi diretamente na percepção da qualidade da obra e na sua conseqüente apreciação ou depreciação estética. Para uma composição gráfica ser considerada "bonita" pelos Wauja é necessário que ela expresse absoluta qualidade técnica e que seja preferencialmente de difícil execução (ehejuapai).

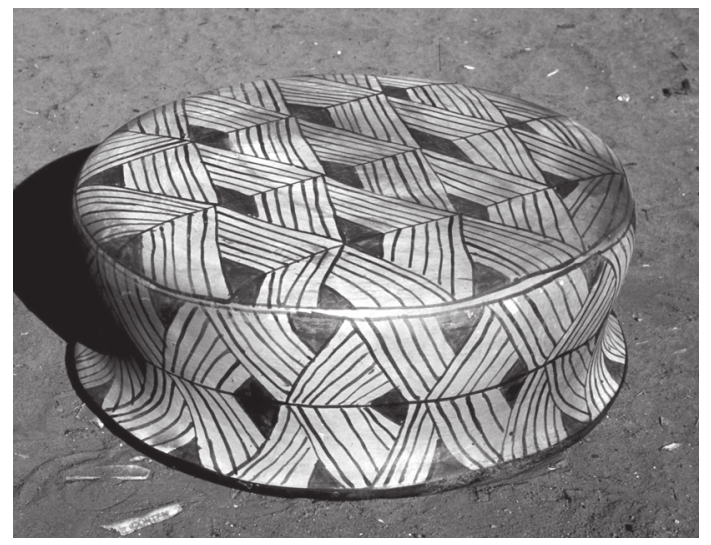

Figura 2 - Lateral e fundo externo de uma panela kamalupo pintada com uma composição gráfica do motivo kupato onabe (espinha de peixe). Fabricada em 1998-9. 78,6 cm de diâmetro no fundo externo.

A qualidade técnica corresponde à nitidez, homogeneidade e firmeza do traço. A dificuldade de execução é uma característica que não só confirma a destreza técnica, mas também a capacidade interpretativa do desenhista. Um desenho difícil é definido por quatro características, pelo menos. Entretanto, somente em alguns casos todas surgem simultaneamente numa mesma composição. Uma característica 


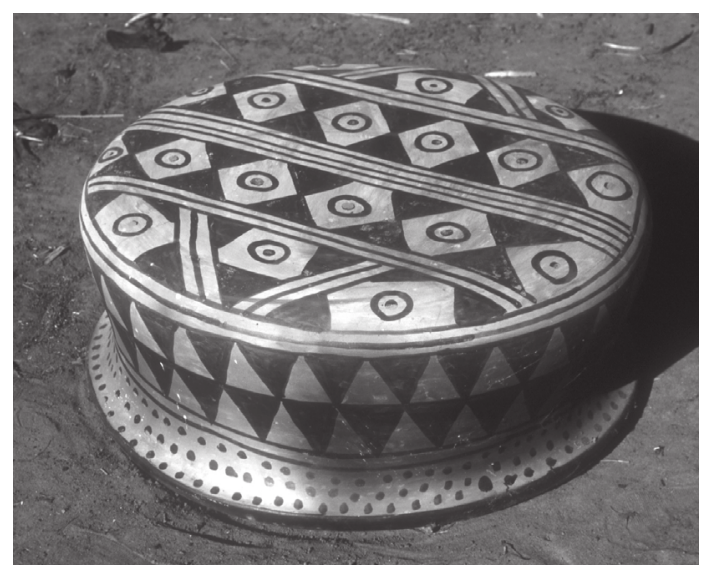

Figura 3 - Lateral e fundo externo de uma panela kamalupo pintada com uma composição gráfica dos motivos temepiana (motivo de cobra jibóia), kulupienê ("peixe"), kuwajata (escama de curimatá) e weri-weri (pontos). Fabricada em 1998-9. 82,5 $\mathrm{cm}$ de diâmetro no fundo externo.

fundamental é a perfeita correspondência entre simetria e ritmo (Figuras 2, 3 e 4). Outra característica do desenho difícil é a composição com, no mínimo, três motivos gráficos diferentes ocupando todo o espaço plástico (Figura 4) e respeitando a distribuição hierárquica dos motivos do centro para a periferia do objeto. Nesse tipo de desenho não pode haver espaços vazios entre os motivos e suas seções.

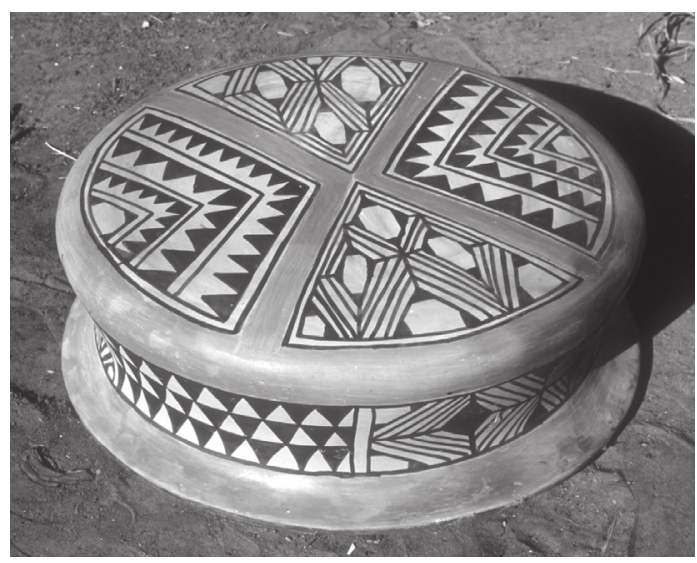

Figura 4 - Lateral e fundo externo de uma panela kamalupo pintada com uma composição gráfica dos motivos kulupienê ("peixe"), Atujuwá opaka (rosto da máscara Atujuwá), mitsewenê (dente de piranha), kuwajata (escama de curimatá) e walamá oneputaku (cabeça de sucuri). Fabricada em 1998-9. 88,2 cm de diâmetro no fundo externo.
Ainda que o desenhista tenha optado por elaborar seu desenho com um único motivo, ele pode estar diante de um desafio maior do que aquele que optou por uma composição repleta de motivos diferentes. Embora as simetrias e ritmos sejam simples, alguns motivos são complexos, sobretudo o kulupiene e o kupato onabe (espinha de peixe, Figura 2), que são motivos repletos de linhas retas paralelas e/ou perpendiculares. A grande dificuldade reside exatamente em fazer coincidir simétrica e ritmicamente todas as linhas retas em uma superfície circular ou cilíndrica respeitando uma distribuição hierárquica dos motivos. A dificuldade de execução do desenho funciona como um grau superlativo de beleza: quanto mais difícil for a execução, "mais bonito" será considerado o desenho ornamental. Um desenho vale o conhecimento e o tempo investidos para torná-lo "bonito".

As características formais próprias do desenho considerado "feio" (aitsaawojotopapai, literalmente "não-bonito") pelos Wauja são exatamente opostas ao desenho awojotopapai ("bonito"), com o detalhe de que podem ser feitos com os mesmos motivos gráficos em ambos os casos. A característica mais visível do desenho "feio" é a ausência de simetria e ritmo, o que demonstra que o desenhista não sabia (ou não quis) vencer o desafio do dimensionamento proporcional dos motivos no espaço plástico. Às vezes o desenho é simétrico, mas o motivo escolhido é simples demais para ele ser considerado um desenho realmente bonito. Portanto, um desenho aitsa-awojotopapai ("feio") é quase sempre considerado aitsaehejuapai ("não-difícil"). 
Estudar o grafismo na cerâmica wauja tendo apenas a ornamentação dos artefatos em circulação como material de investigação impõe uma séria limitação devido à rapidez com que as pinturas desaparecem quando as panelas e os torradores de beiju são levados ao fogo. Outro detalhe importante é que as panelas novas são zelosamente guardadas (escondidas, talvez), encobertas por panos velhos para protegerem as pinturas da poeira. Ademais, algumas panelas permanecem sem pintura (biscoito) até poucos dias antes de serem oferecidas como pagamento ou destinadas ao uso da casa. Um estudioso de antropologia da arte logo perceberá que, entre os Wauja, muito do que ele gostaria de ver desapareceu com o uso ou está encoberto, pela fuligem, pela escuridão ou por panos sujos, ou está na memória dos sonhos e transes. Tais indícios sugerem que o processo de produção dos desenhos ocupam um lugar mais central do que a sua apreciação: trata-se, muito provavelmente, de uma arte menos para ser vista do que para ser feita, ou melhor, para ser vista por um tempo muito curto e/ou em situações apoteóticas.

A fim de obter uma documentação mais extensa e precisa sobre as categorias estéticas wauja, solicitei a um grupo de quatro ceramistas do sexo feminino ${ }^{15}$ que

15 Entre os Wauja, tanto homens quanto mulheres dominam as técnicas de fabricação e pintura da cerâmica. As mulheres iniciam seu aprendizado na reclusão pubertária apenas produzindo pequeninas panelas. Os homens aprendem modelagem depois dos 30 ou 40 anos de idade, quando geralmente já participam de um circuito de prestações rituais que os obriga a produzir panelas-pagamento, ou, mais raramente, quando se interessam espontaneamente pela arte da cerâmica. Mesmo não dominando as técnicas de modelagem, a maioria dos homens é capaz de fazer os desenhos geométricos que decoram as panelas, mas segundo competências variadas.

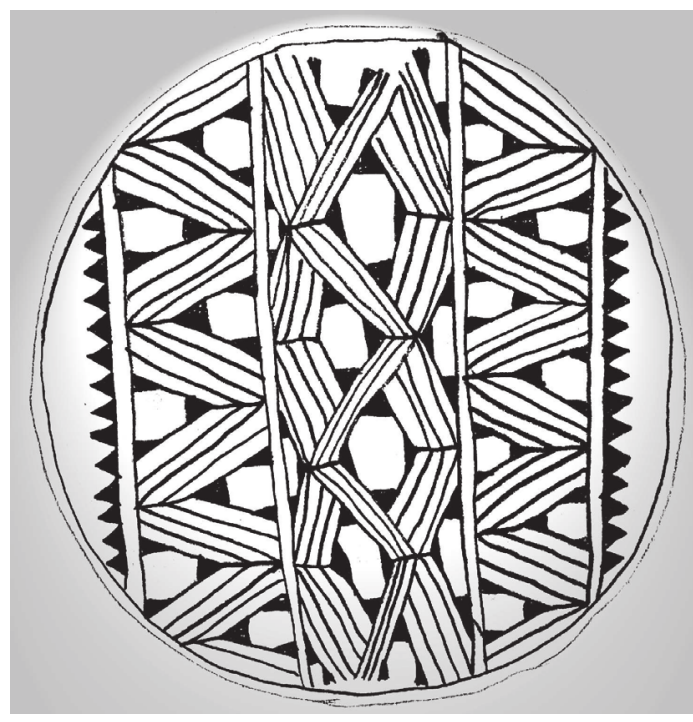

Figura 5 - Composição gráfica para fundo de panela com os motivos kulupienê e mitsewenê. Grafite sobre canson, 23x33 cm, 1998.

desenhassem em papel as composições gráficas consideradas awojotopapai e aitsaawojotopapai. Elas iniciaram, com muito interesse, pelas composições "bonitas" (Figuras 5 e 6). Quando eu solicitei que fizessem desenhos "feios", disseram-me de imediato que não sabiam fazer desenhos "feios", quer dizer: não sabiam criá-los. Mudei o sentido do meu pedido sugerindo que elas tentassem se lembrar de desenhos

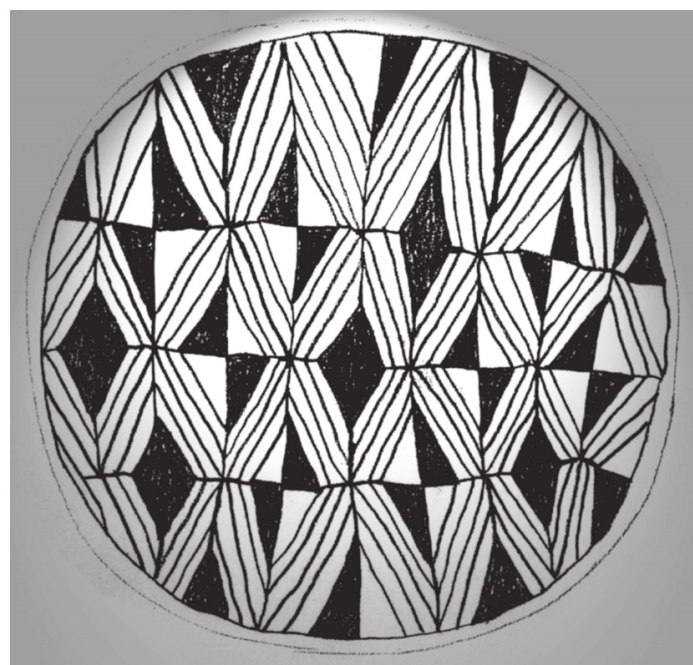

Figura 6 - Composição gráfica para fundo de panela com os motivos kunye kunye jutogana e walamá oneputaku. Grafite sobre canson, $23 \times 33 \mathrm{~cm}, 1998$.

\section{artigos}




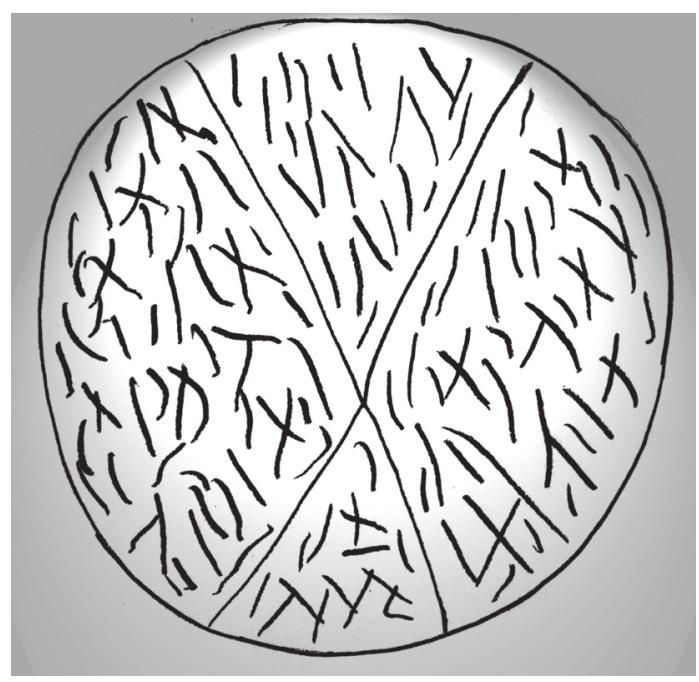

Figura 7 - Composição gráfica para fundo de panela com o motivo pojojeká. Grafite sobre canson, 23x33 cm, 1998.

"feios" alguma vez vistos e que usassem suas memórias visuais para reproduzi-los nos papéis que eu lhes oferecia. Então, com menor relutância, mostraram-me, ao longo de sessões de desenhos que duraram algumas semanas, aquilo que os Wauja consideram fora dos limites de aceitabilidade e agradabilidade estética. As Figuras 7 e 8 são exemplos resultantes desse meu pedido. Terminados os

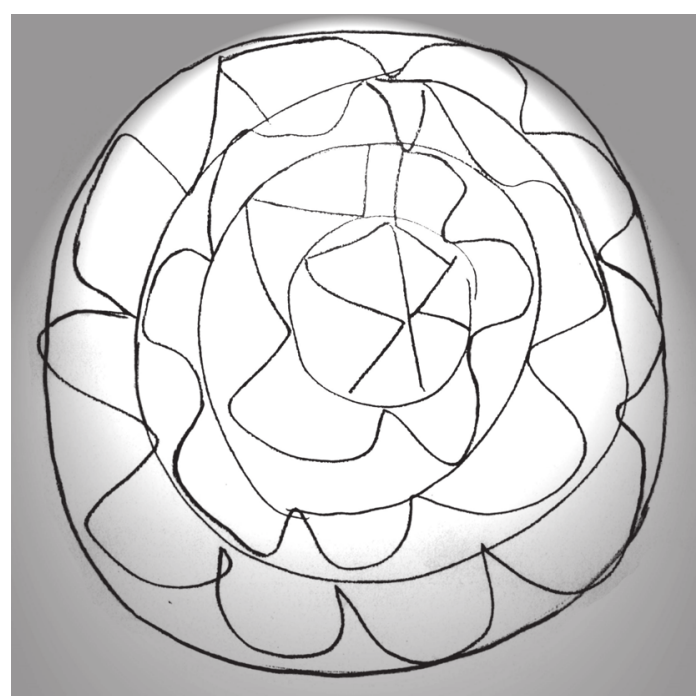

Figura 8 - Composição gráfica para fundo de panela com o motivo pojojeká. Grafite sobre canson, $23 \times 33$ cm, 1998. desenhos, elas não contiveram seus risos: aquilo parecia realmente ridículo aos olhos de um Wauja. Esses dois desenhos, de simetria incipiente e feitos com motivos gráficos bastante incomuns (pojojeká e abonapu, respectivamente "rabiscos" e "caminho"), diferenciam-se expressivamente dos outros desenhos considerados "bonitos", feitos por essas mesmas ceramistas. Ao comparar os quatro desenhos (5, 6, 7 e 8), é notável como tal reduzido número de exemplos consegue descrever as bases estéticas sob as quais o sistema gráfico wauja está assentado. Mais exemplos apenas confirmariam que, entre os desenhos "bonitos" e os "feios", há uma sensível escala de valores que vai da simetria à assimetria.

Volto às minhas informantesdesenhistas que disseram não saber fazer (i.e. criar) desenhos "feios". Isso talvez seja a indicação de que a fealdade é algo fora do espaço imaginativo que se concebe para a criação artística. A fealdade existiria por si, seria da ordem do dado, posicionandose inversamente à beleza, que seria da ordem do construído - do controle e do contato com o mundo extra-humano a partir da doença, do longo aprendizado e do labor meticuloso, portanto. Noto que quando entreguei os papéis às desenhistas elas começaram pela execução de composições consideradas "bonitas" (Figuras 5 e 6), e foram desenho a desenho - em uma seqüência de aproximadamente doze pranchas para cada desenhista distanciando-se dos padrões de beleza até alcançarem completamente o nível dos desenhos "feios" (Figuras 7 e 8), chegando a uma idéia de ineficácia estética. 
Para entendermos questões de socialidade, envolvidas na produção de objetos graficamente decorados, em âmbitos rituais ou não, as categorias de "bonito" e "feio" devem ser transpostas, respectivamente, para as noções de eficácia e ineficácia estéticas. Ambas as noções, tomadas aqui como categorias analíticas, são emicamente descritas pelos termos apapalai-iyajo (objetos autênticos, verdadeiros, legítimos) e apapalai-malu (objetos insuficientes, imprestáveis, falsos). Os objetos-iyajo e -malü movimentam-se de modos distintos. Os primeiros migram da periferia da aldeia para o centro (ou em certos casos são feitos aí mesmo) e depois retornam para a periferia, em geral, para as casas dos "donos" rituais. Já os objetos objetos-malũ raramente saem do lugar (ou seja, são feitos em seu próprio local de uso), e quando há alguma circulação, eles a fazem pela linha periférica da aldeia ${ }^{16}$. Se acionarmos uma chave stratherniana, notaremos os objetos eficazes encapsulados por uma "socialidade política" (Strathern, 1988: 96-97), na qual eles têm uma participação ativa na produção de imagens de "nobreza" e prestígio político. Todavia, eles também estão encapsulados por uma "socialidade doméstica", o que os coloca numa posição de estreita intersecção entre ambas as "socialidades". Ou seja, os objetos eficazes são tanto uma questão de ações coletivas (aqui lidas como objetivos comuns e gerais de produção ritual) quanto de relações particulares (aqui lidas como as trocas, equilibradas ou não, entre um patrocinador ritual e seus

16 Há, como veremos a seguir, uma exceção, que é a venda de objetos esteticamente ineficazes para as lojas de artesanato. performers). Mais adiante voltaremos rapidamente a esse assunto ${ }^{17}$.

De volta às pranchas das informantesdesenhistas. Somente alguns dias mais tarde, quando uma jovem aproximou-se cheia de curiosidade a fim de olhar os desenhos que eu estava a organizar e comparar, pude compreender melhor as suas evitações em produzir desenhos "feios" e, depois, o deboche feito sobre eles. A jovem ficou espantada diante dos desenhos "feios" e, percebendo que não havia ninguém por perto, atrevidamente me perguntou quem os tinham feito. Respondilhe que não poderia revelar a identidade das pessoas. Muito segura de si, a jovem disse que não precisava saber, pois aqueles desenhos só podiam ser, segundo ela, obras de pessoas sem qualquer discernimento. Seu julgamento não se aplica às desenhistas que os fizeram, pois, com cuidado e inteligência, elas conseguiram traduzir graficamente aquilo que está no terreno da ineficácia estética e explicar as relações entre as características formais e as concepções estéticas no âmbito do desenho decorativo geométrico.

A dinâmica expressiva idiossincrática no sistema gráfico wauja permite notar uma relação mais ou menos "frouxa" entre as regras do desenho "bonito" e a ação concreta de cada desenhista. Este é um sistema de limites expressivos razoavelmente extensos e de rigidez moderada, digo isso pensando como base comparativa o sistema gráfico KayapóXikrin, tal qual descrito por Lux Vidal (1992). Ultrapassar os limites do modelo tradicional - este sendo precisamente os

17 Para um aprofundamento sobre o mesmo, ver Barcelos Neto (2004: capítulo 7). 
desenhos de Arakuni, o próprio modelo mítico do sistema gráfico - leva à produção de desenhos muitas vezes distanciados dos padrões de eficácia estética wauja. É o seu enquadramento numa escala gradativocontrastiva de valores estéticos que permite criar distinções entre as esferas rituais e domésticas de circulação dos objetos decorados.

Os aspectos plásticos do desenho simétrico e ritmado e do desenho assimétrico e sem ritmo só podem ser tomados em consideração para uma etnoestética quando eles passam a marcar e a afirmar o próprio lugar da beleza na socialidade wauja. Esse lugar é preenchido por uma idéia de que a beleza, mais do que produto, é algo que produz relações por meio de uma interação ativa entre a distribuição de poderes rituais e suas contra-prestações.

As diferenças entre os quatro desenhos acima (Figuras 5, 6, 7 e 8) apontam que as características próprias da beleza gráfica expressam-se na simetria e no ritmo, mas estes são os aspectos de reconhecimento formal que os Wauja me apontaram depois de muito perguntar e comparar o corpus que venho reunindo desde 1994. Resta agora explorar os contextos em que beleza e fealdade adquirem saliências sociais.

\section{IV - Os lugares sociais da beleza e da fealdade}

Os Wauja possuem vivo interesse em observar desenhos e pinturas e avaliá-los em silêncio, para si próprios. Apreciadores discretos, raramente ofenderiam com seus julgamentos alguém que entre eles não possui competência para pintar, ou que, por ventura, tenha feito pinturas "feias". Dificilmente um deles faria um julgamento estético explícito sem antes saber exatamente quem executou a obra, mesmo se intimamente a considerar "bonita". As formações de duas coleções etnográficas, uma em 1998, para o Museu de Arqueologia e Etnologia da Bahia, e a outra em 2000, para o Museu Nacional de Etnologia de Lisboa, ajudaram-me a entender essas atitudes e os espaços sociais de circulação dos objetos esteticamente eficazes e ineficazes.

Os rituais wauja, por menores que sejam, geram pagamentos que variam desde o mínimo de três panelas grandes (tipo kamalupo) até quarenta panelas de tamanhos menores (tipo makula) e variados. Poucos são os objetos passíveis de compor uma lista de pagamento, ademais só podem ser incluídos aqueles de primeira qualidade. Panelas são os principais (ou muitas vezes os únicos) objetos que os Wauja dispõem como pagamento em rituais interaldeões. Soma-se a isso o fato de os anfitriões de outras aldeias sempre esperarem como pagamento dos Wauja suas kamalupo, pois, conforme já mencionado na literatura (Agostinho, 1974; Heckenberger, 1996) eles são os únicos que, no Alto Xingu, fabricam as grandes panelas usadas para cozinhar o caldo venenoso da mandioca.

Para os Wauja, não constitui um problema se peças-malu $\tilde{\sim}^{18}$ são destinadas aos museus, à

18 Os objetos malü (falsos, imprestáveis, incapazes, ilegítimos) não possuem eficácia estética, portanto não podem participar de contextos rituais. Eles são também chamados de "paraguai", em alusão aos objetos de baixa qualidade contrabandeados do Paraguai. 
Artíndia ou às lojas de artesanato $^{19}$, o que elas não podem é servir de pagamento aos "donos" de rituais ou aos xamãs visionáriodivinatórios (neste último caso, a alta qualidade do pagamento tem uma relação direta com a efetiva recuperação do doente). Aliás, os lugares acima mencionados podem naturalmente receber peças "feias", pois, como me dizia o chefe Atamai, os brancos "não entendem nada mesmo do nosso desenho" 20 .

$\mathrm{Na}$ formação da segunda coleção, confrontei-me com maior intensidade com a questão das fronteiras de circulação dos artefatos e da sua valoração estética. Desde

19 Vale aqui uma breve contextualização das categorizações do sistema de objetos no âmbito das relações com os brancos. Há, no Alto Xingu, um estilo de mercadorias especialmente inventado para suprir, por meio de vendas ou trocas, as necessidades dos índios por bens industrializados. Muitos objetos vagabundos ou descartáveis levados pelas centenas de brancos que passam pelo Parque todos os anos já têm seus correspondentes no artesanato local. O volume desse comércio tem crescido anualmente, abrangendo uma diversidade cada vez maior de produtos. Recentemente, uma família wauja trocou um conjunto de máscaras "paraguai" - noto que essa categoria, que tem imediata equivalência semântica com o afixo-modificar -malũ é extremamente operante - por um gerador usado para assistir televisão. Apesar desse imenso comércio, circula no Alto Xingu a idéia de que as coisas "originais", "de verdade" (iyajo), devem ser preservadas do comércio com os brancos. Mas, se forem solicitadas por estes, as tais coisas "originais" deverão ser pagas "com muito dinheiro, com barco, motor, Toyota, placa solar, motoserra”, o que indica que não há nenhuma idéia hegemônica nesse sentido. Não obstante, os limites desse comércio são virtual ou, às vezes, concretamente controlados pelos chefes mais tradicionais a fim de preservar, sobretudo, os rituais das flautas Kawoká e as canções xamânicas.

20 Claro que não são todos os brancos que recebem objetosmalũ. Atamai refere-se aqui ao branco "médio", cuja relação com os índios é mediada por variados agentes, governamentais ou não. Há, obviamente, várias lojas com belíssimos objetos wauja, mas isso não quer dizer que eles sejam necessariamente de natureza-iyajo ("autênticos" ou de origem ritual). Muitos desses objetos são peças de "arte turística" que chegaram a um nível de refinamento insistentemente exigido pelas próprias lojas. o início, os Wauja sabiam que as panelas destinavam-se a um museu. Como a orientação do Museu Nacional de Etnologia de Lisboa era pela coleta de artefatos com marcas de uso, perguntei aos Wauja se eles podiam vender suas panelas pretas de fuligem. Logo percebi que as únicas que eles tinham para substituir aquelas eram as suas panelas destinadas a pagamentos rituais. Efetuar tais substituições pareceu-me uma decisão que os Wauja dificilmente tomariam. Assim, na primeira viagem (fevereiro a abril de 2000), consegui a compra de apenas duas kamalupo. Uma tinha sido deliberadamente feita para a venda, pois a sua dona queria comprar uma máquina de costura. A outra foi encomendada e pude pedir que fosse confeccionada e pintada tal qual as panelaspagamento para os rituais.

A aquisição de panelas grandes foi uma tarefa que se tornou mais difícil ao longo da formação da coleção. $\mathrm{Na}$ segunda viagem (junho a agosto de 2000), notei que os Wauja tinham evitado me mostrar suas kamalupo remanescentes. As panelas kamalupo esteticamente eficazes, objetos de meu enfoque de coleta, já nascem potencialmente para ser objetos rituais: é no contexto do ritual que elas adquirem, sob a forma de pagamento, a plenitude desse status. Em geral, as panelas esteticamente ineficazes são aquelas que não têm um dono previsto, portanto elas poderão ser usadas na própria casa onde foi fabricada - ou seja, elas não percorrem o circuito periferia-centro da aldeiaperiferia, que caracteriza a circulação dos objetos de pagamento ritual -, vendidas aos brancos ou trocadas por outros objetos de valor semelhante ao delas. Sua ineficácia estética não diminui sua funcionalidade, 
mas limita sua inserção em contextos solenes, como os rituais interaldeões ou os rituais xamânicos de resgate da alma de um doente em estado grave.

Os Wauja têm claramente a preocupação de distinguir esteticamente os objetos feitos como pagamento ritual dos demais objetos. Num contexto como o de uma festa de apapaatai, uma panelapagamento precisa seguir as expectativas wauja de eficácia estética: motivos complexos dispostos em perfeita simetria numa superfície circular-cilíndrica, demonstrando um alto grau de domínio do repertório e das técnicas. As panelas devem ser pintadas desse modo, sobretudo, em respeito aos apapaatai e ao "dono" ritual que as recebe como pagamento. Artefatos esteticamente ineficazes não contribuem para o bemestar do doente (ou do ex-doente, caso seu estado já tenha se normalizado) e nem para o contentamento dos apapaatai. Produzir coisas-malũ como pagamento ritual é altamente condenável.

Ao serem indagados sobre o porquê da pintura, os Wauja não oferecem muito mais do que lacônicas respostas, do tipo: "é pra ficar bonito". E por que tem que ficar bonito? "Para ficar alegre", respondem. Grande parte da produção gráfica wauja é, na verdade, um esforço para gerar o estado de kotepemonapai (alegria), o qual é um efeito de tudo o que é belo. Produzir desenhos "feios" em contextos como o dos rituais de apapaatai pode pesar negativamente para o desenhista; por isso, apenas pessoas com reconhecida competência estão aptas a assumir a responsabilidade de ser kawoká- $m o n a^{21}$. Do ponto de vista wauja, a produção de desenhos "bonitos" gera a satisfação estética dos apapaatai. Portanto, cabe aos desenhos contribuir para o estado de kotepemonapai (alegria). Muito do esforço das festas de apapaatai objetiva produzir esse estado, o qual, ao permitir subtrair a agressividade $^{22}$ originada pela agência patológica dos apapaatai e ao direcionar a ação ritual no sentido da domesticação destes, enseja a cura do doente. É a beleza que cura.

No mundo xinguano, a circulação de objetos belos é um sinal de enobrecimento tanto de quem oferece quanto de quem recebe. Os Wauja levam extremamente a sério essa proposição, a ponto de lançarem certas coisas "feias" para o campo conceitual da feitiçaria. Eles fazem questão de enfatizar que seus objetos de uso cotidiano, recebidos como pagamento ritual, foram "belos" um dia. Como se pode facilmente notar, passado algum tempo de uso, a fuligem apaga por completo a pintura das panelas, a poeira e

21 Categoria social de indivíduos que assume a persona dos apapaatai em rituais de cura e se responsabilizam pela produção de "objetos de luxo", roças, canoas e demais artefatos que sustentam a continuidade dos próprios rituais que eles performatizam. A responsabilidade de um kawoká-mona é tão grande quanto a de um xamã que resgata almas raptadas pelos apapaatai. Em uma abordagem musicológica, Piedade (2004), mostra que o principal flautista de Kawoká (Kawoká topá) jamais pode errar a melodia, sob o risco de "morrer" (i.e. ficar gravemente doente) ou de sofrer graves infortúnios. Errar a melodia pode ainda agravar o estado do doente ou, em hipóteses mais remotas, matá-lo.

22 O controle da agressividade tem sido um importante tema da pesquisa antropológica no Alto Xingu, exatamente por ele ser, no pensamento nativo, objeto das mais refinadas elaborações sociológicas, as quais foram descritas a partir da noção de ifutisu, que engloba valores de respeito-generosidade-pacifismo (Basso, 1973; Gregor, 1994 e 2001; Viveiros de Castro, 1977; Barcelos Neto, 2004). 
a terra impregnam nos cestos, e as pinturas das pás de beiju e desenterradores de mandioca descascam, dando a impressão de que esses objetos nunca foram pintados. Porém, a sua beleza pretérita fica registrada na memória de quem ofereceu e de quem recebeu. Sim, a beleza também está ligada ao ato. Ninguém está preocupado em conservar os objetos porque eles são belos, e sim em repetir essa beleza numa produção contínua de objetos. A preocupação maior é em oferecer belos objetos como pagamento ritual.

A dedicação ao ritual pode tomar mais da metade da vida de um indivíduo - isso se ele decidir ter uma vida ritual intensa, o que é bastante comum entre os Wauja. A posição social de "dono" (patrocinador) de rituais de apapaatai implica vários investimentos a médio e longo prazos, como o plantio de roças e a retenção de genros e filhos em uma mesma unidade residencial. O "dono" de uma festa de apapaatai, que é sempre um exdoente, deverá, durante todo o ciclo da festa, alimentar seus kawoká-mona e estes deverão retribuir o alimento recebido com artefatos e/ou trabalho, e executar as performances rituais específicas dos apapaatai que eles "representam".

Tankwara, um clarinete-apapaatai, tem atualmente o chefe Atamai como um dos seus "donos" rituais. Tankwara, através dos kawoká-mona, construiu, para o referido chefe, uma casa com todas as insígnias de chefia: dimensões significativamente superiores às demais casas, frisos decorativos no interior de toda a casa e enfeites suspensos (na verdade, troncos com raízes) amarrados na parte superior externa. As atividades de Tankwara sob o patrocínio de Atamai duram desde 1993, pelo menos. No ano de 1999, quando a grande casa foi concluída, o chefe recebeu dos seus kawoká-mona cinco panelas e uma roça como pagamentos rituais. Cada uma das panelas corresponde a um dos cinco tubos que invariavelmente constituem o conjunto dos clarinetes Tankwara, e cada tubo corresponde a um kawoká-mona, formando, portanto, um quinteto musical. Os clarinetistas ofereceram ao chefe as panelas-pagamento em ordem decrescente de acordo com o tamanho do tubo que cada um tocava. Este exemplo demonstra como a "obsessão formal" wauja integra estruturalmente domínios visuais, musicais e coreográficos a um só tempo.

Das cinco panelas que mencionei acima, três (Figuras 2, 3 e 4) continuavam intactas, guardadas no interior da grande casa de Atamai, até a minha saída do campo em outubro de 2000. Elas são objetos da mais alta eficácia estética wauja. Esta qualidade estética das panelas, claramente personalizada em torno da figura do chefe Atamai, relaciona-se a seu contexto: a festa dos clarinetes-apapaatai Tankwara. Apenas os artefatos rituais atingem tais níveis de excepcionalidade gráfica, o trocano (Pulu Pulu), os grandes pilões de Yamurikumã, os troncos funerários do Kaumai (ou Kwarip, na língua kamayurá), as máscaras Atujuwá e as adolescentes recém saídas da reclusão ${ }^{23}$, através das pinturas aplicadas em seus corpos.

As jovens reclusas passam até dois anos preparando-se para o dia em que sairão para dançar num ritual interaldeão e, logo em

23 O leitor encontrará, nas monografias e artigos de Gregor (1970 e 1982) e Viveiros de Castro (1977 e 1979), descrições e análises detalhadas sobre o complexo xinguano das reclusões. 
seguida, para o casamento. A pintura e os adornos são as últimas coisas que elas recebem no dia da festa. Nenhuma outra mulher além das adolescentes ostentará o motivo kulupiene, o mais "belo", segundo os Wauja. Aliás, na festa do Yawari (caracterizada por duelos rituais com dardos), a que serve de objeto para esta análise, todas as jovens recém saídas da reclusão possuíam perfeitas pinturas do kulupiene. As mulheres que já passaram por essa experiência devem ficar "menos bonitas" - noto enfaticamente que os Wauja dificilmente diriam isso -, pois a beleza das reclusas deve ser incomparável. Tal como entre os Piro (Gow 1999), a reclusa wauja incorpora as dimensões máximas da beleza.

Como disse antes, o mais importante para os Wauja em termos de produção gráfica é o conjunto-matriz de motivos representado pela "roupa"-cobra de Arakuni. Aliás, é por uma razão explícita que os desenhos de Arakuni são chamados de yanaiki-iyajo ("desenhos de verdade"). Em se tratando de artefatos e pessoas integradas em solenidades distintas das festas e "brincadeiras", a utilização do yanaiki-iyajo é indispensável para expressar a mais alta eficácia estética segundo o pensamento wauja. Nessas ocasiões, os desenhos de Arakuni, especialmente os motivos kulupiene e kupato onabe, são reproduzidos com imensa estabilidade plástica e fidelidade a um pequeno número de padrões compositivos. Neste caso, há um modo de produção dos desenhos que restringe certas liberdades criativas individuais. Tal modo produtivo reflete o conservadorismo estético wauja, ele próprio um emblema do que poderia ser enquadrado como uma noção wauja de cultura (Ireland, 2001).

Voltando ao domínio da circulação ritual das kamalupo, noto que a minha dificuldade em adquiri-las foi uma resposta a minha condição de estrangeiro. Eu, branco, totalmente marginal ao sistema ritual, não partilhava dos laços sociais que me permitiriam adquirir os genuínos artefatos do mais alto valor estético wauja. Embora os Wauja reconheçam a equivalência entre valor monetário e valor/eficácia estética, e como bons vendedores de artesanato procuram usá-la da melhor maneira, há contextos em que essa lógica é totalmente falha. Como eu tinha o objetivo de recolher objetos da alta pintura wauja para a coleção do Museu Nacional de Etnologia de Lisboa, consultei o chefe Atamai sobre a possibilidade da venda, de acordo com um preço que ele estipularia, das suas três panelas de Tankwara remanescentes. Ele disse que não poderia vender nem mesmo uma só: "isso é pagamento de Tankwara, não posso desrespeitar quem está me ajudando, se eu fizer isso eu morro". O que estava em questão eram valores éticos muito superiores a uma possível equalização monetária, pois a venda das panelas teria como conseqüência a infração de um sistema moral que sustenta o próprio status do chefe e a sua reprodução social.

Frustrada a tentativa, como tantas outras, resolvi encomendar uma pintura especial para uma panela nukãa ou makula ainda totalmente biscoito. Depois de muita busca, encontrei um indivíduo que tinha uma makula em condição de biscoito, e que é ao mesmo tempo um excelente desenhista. Pedi que ele reproduzisse o desenho kupato onabe da panela de Tankwara de Atamai 
(Figura 2). Fomos até a casa do chefe para que o desenhista "contratado" observasse o exato padrão composicional que eu queria para o kupato onabe. No dia seguinte, o encontrei, na área de luz da porta frontal da casa de Atamai, a copiar, em um pedaço de papel, o desenho da panela. Quando ele me viu por ali, apenas levantou os olhos e me disse baixinho, em português, que estava "aprendendo" (i.e. estudando) o desenho. Ele próprio parecia estar fascinado com a qualidade da composição gráfica que tinha diante de si. $\mathrm{Na}$ tarde do dia posterior, teve lugar, na sua casa, o processo de pintura da panela biscoito, delicadamente lisa, uma peça de modelagem e cozimento perfeitos. Em duas horas e meia de meticuloso trabalho, toda a superfície branca externa converteu-se em uma obra-prima repleta de um só motivo, e o interior e o lado superior da borda achatada, característica típica das panelas makula, inteiramente pretos. Aliás, essa panela foi pintada com a melhor e a mais difícil das técnicas de pintura, aquela que emprega o sumo da casca de uma árvore chamada mawatã. Ao fim do trabalho, notei que o desenhista tinha deliberadamente corrigido todos os pequenos defeitos do desenho que lhe serviu anteriormente de modelo, demonstrando a eficiência do seu estudo.

Dois dias antes da minha partida, perguntei se ele embalaria a panela no cesto cargueiro que eu tinha lhe oferecido especialmente para isso. Com um certo acanhamento e sem dar qualquer explicação, disse-me simplesmente que não venderia mais a panela para o Museu. Voltei sem a bela encomenda, que ficou para trás, guardada nas entranhas escuras da casa onde ela nasceu, a espera de algum ritual.
Artigo aceito para publicação em 14 de dezembro de 2004.

\section{Bibliografia}

AgOSTINHO, Pedro. Kwarip. Mito e ritual no Alto Xingu. São Paulo: EPU, EDUSP, 1974.

BARCELOS NETO, Aristóteles. Panelas que cantam e que devoram: a cerâmica Wauja. In: BRITO, J. P. (org.), Os Índios, Nós. Lisboa: Museu Nacional de Etnologia, 2000. p. 136-153.

BARCELOS NETO, Aristóteles. Apontamentos para uma iconografia histórica xinguana. In: FRANCHETTO, B. e HECKENBERGER, M. (orgs.). Os povos do Alto Xingu: história e cultura. Rio de Janeiro: Editora UFRJ, 2001. p. 193218.

BARCELOS NETO, Aristóteles. $A$ arte dos sonhos: uma iconografia ameríndia. Lisboa: Assírio \& Alvim, Museu Nacional de Etnologia (Colecção Coisas de Índios), 2002.

BARCELOS NETO, Aristóteles. Apapaatai: rituais de máscaras no Alto Xingu. Tese de Doutorado em Antropologia Social, Universidade de São Paulo, 2004.

BASSO, Ellen Becker. The Kalapalo Indians of Central Brazil. New York: Holt, Rhinehart \& Winston, 1973.

COElHO, Vera Penteado. Alguns aspectos da cerâmica dos indios Waurá. 
Coleção Musen Paulista: Série Ensaios, São Paulo, 4, 1981. p. 55-84.

COELHO, Vera Penteado. Die Waurá: Mythen und Zeichnungen eines brasilianisches Indianer Stammes. Leipzig: Gustav Kiepenheuer Verlag, 1986.

COELHO, Vera Penteado. Zeichnungen der Waurá Indianer. In: MÜNZEL, M. (org.). Die Mythen Sehen: Bilder und Zeichen von Amazonas. Frankfurt: Museum für Völkerkunde, 1988. p. 468-532.

COELHO, Vera Penteado. Motivos geométricos na arte Waurá. In: COELHO, V.P. (org.), Karl von den Steinen: um século de antropologia no Xingu. São Paulo: EDUSP/FAPESP, 1993. p. 591-629.

COELHO, Vera Penteado. Figuras zoomorfas na arte Waurá: anotações para o estudo de uma estética indígena. Revista do Museu de Arqueologia e Etnologia, São Paulo, 5, 1995. p. 267-281.

FÉNELON COSTA, Maria Heloísa. O mundo dos Mehináku e suas representações visuais. Brasília: Editora da UnB, 1988.

FRANCHETTO, Bruna e HECKENBERGER, Michael (orgs.). Os povos do Alto Xingu: história e cultura. Rio de Janeiro: Editora UFRJ, 2001.

GOW, Peter. Visual Compulsion: Design and Image in Western Amazonian
Cultures. Revindi, Budapest, 2, 1988. p. 19-32.

GOW, Peter. Piro Designs: Painting as Meaningful Action in an Amazonian Lived World. Journal of the Royal Anthropological Institute, Londres, n.s., 5, 1999. p.229-246.

GREGOR, Thomas. Exposure and Seclusion: a Study of Institutionalized Isolation among the Mehinaku Indians of Brazil. Ethnology, 9, 1970. p. 234-250.

GREGOR, Thomas. Mehináku. O drama da vida diária em uma aldeia do Alto Xingu. São Paulo: Cia. Editora Nacional, 1982.

GREGOR, Thomas. Symbols and Rituals of Peace in Brazil's Upper Xingu. In: GREGOR, T. e SPONSEL, L.E. (orgs.). The Anthropology of Peace and Nonviolence. Boulder e Londres: Lynne Rienner Publishers, 1994. p. 241-257.

GREGOR, Thomas. Casamento, aliança e paz intertribal. In: B. FRANCHETTO, B. e HECKENBERGER, H. (orgs.). Os povos do Alto Xingu: história e cultura. Rio de Janeiro: Editora UFRJ, 2001. p. 175-192.

HECKENBERGER, Michael. War and peace in the shadow of empire: sociopolitical change in the Upper Xingu of Southeastern Amaronia, A.D. 1400-2000. Tese de Doutorado em Arqueologia. Pittsburg, Universidade de Pittsburg, 1996. 
HECKENBERGER, Michael. Estrutura, história e transformação: a cultura xinguana na longue durée, 1000 2000 d.C. In: FRANCHETTO, B. e HECKENBERGER, M. (orgs.). Os povos do Alto Xingu: história e cultura. Rio de Janeiro: Editora UFRJ, 2001. p. 21-62.

IRELAND, Emilienne Marie. Noções Waurá de Humanidade e de Identidade Cultural. In: FRANCHETTO, B. e HECKENBERGER, M. (orgs.). Os povos do Alto Xingu: história e cultura. Rio de Janeiro: Editora UFRJ, 2001. p. 249-286.

LAGROU, Elsje Maria. Caminhos, duplos e corpos: uma abordagem perspectivista da identidade e alteridade entre os Kaxinawa. Tese de Doutorado em Antropologia Social, Universidade de São Paulo, 1998.

LÉVI-STRAUSS, Claude.Tristes Tropiques. Paris: Plon, 1955.

MENEZES BASTOS, Rafael José de. $A$ musicológica Kamayurá: para uma antropologia da comunicação no Alto Xingu. Brasília: FUNAI, 1978.

MENEZES BASTOS, Rafael José de. Indagação sobre os Kamayurá, o Alto Xingu e outros nomes e coisas: uma etnologia da sociedade xinguara. Anuário Antropológico/94. Rio de Janeiro: Tempo Brasileiro, 1995. p. 227-269.

MENEZES BASTOS, Rafael José de. Ritual, história e política no Alto Xingu: observações a partir dos Kamayurá e do estudo da Festa da Jaguatirica (Jawari).
In: FRANCHETTO, B. e HECKENBERGER, M. (orgs.). Os povos do Alto Xingu: história e cultura. Rio de Janeiro: Editora UFRJ, 2001, p. 335-359.

MENGET, Patrick. Les frontières de la chefferie: remarques sur le système politique du Haut Xingu (Brésil). L'Homme, Paris, 126-128, 1993. p. 5976.

MONOD-BECQUELIN, Aurore. O homem apresentado ou as pinturas corporais dos índios Trumaís. In: COELHO, V.P. (org.). Karl von den Steinen: um século de antropologia no Xingu. São Paulo: EDUSP/FAPESP, 1993. p. 511-562.

PIEDADE, Acácio. O canto do Kawoká: música, filosofia e cosmologia entre os Wauja do Alto Xingu. Tese de doutorado em Antropologia Social. Florianópolis, Universidade Federal de Santa Catarina, 2004.

REICHEL-DOLMATOFF, Gerardo. Beyond the Milky Way: Hallucinatory Imagery of the Tukano Indians. Los Angeles: University of California, Latin American Center Publications, 1978.

RIBEIRO, Berta. Os padrões ornamentais do trançado e a arte decorativa dos índios do Alto Xingu. In: COELHO, V.P. (org.). Karl von den Steinen: um século de antropologia no Xingu. São Paulo: EDUSP/FAPESP, 1993. p. 563-589.

SEEGER, Anthony. Nature and Society in Central Brazil: the Suya Indians of Mato

\section{artigos}


Grosso. Cambridge: Harvard University Press, 1981.

SEEGER, Anthony; DAMATTA, Roberto e VIVEIROS DE CASTRO, Eduardo. A construção da pessoa nas sociedades indígenas brasileiras. Boletim do Museu Nacional, Rio de Janeiro, 32, 1979. p. 213-230.

STEINEN, Karl von den. Durch Central Brasilien. Leipzig: Brockhaus, 1886.

STEINEN, Karl von den Entre os aborígenes do Brasil Central. Revista do Arquivo Municipal, São Paulo, 1940 [1894]. p. 34-52. (Separata).

STRATHERN, Marilyn.The gender of the gift: problems with women and problems with society in Melanesia. Berkeley: University of California Press, 1988.

TAYLOR, Anne-Christine. Les masques de la mémoire: essai sur la fonction des peintures corporalles jivaro. L'Homme, 165, 2003. p. 223-247.

VELTHEM, Lúcia van. O belo é a fera: a estética da produção e da predação entre os Wayana. Lisboa: Assírio \& Alvim, Museu Nacional de Etnologia (Colecção Coisas de Índios), 2003.

VIDAL, Lux. A pintura corporal e a arte gráfica entre os Kayapó-Xikrin do Cateté. In VIDAL, L. (org.). Grafismo indígena. Estudos de antropologia estética. São Paulo: EDUSP/FAPESP/Studio Nobel, 1993. p. $143-189$.
VIDAL, Lux (org.). Grafismo indigena. Estudos de antropologia estética. São Paulo: EDUSP/FAPESP/Studio Nobel, 1993.

VIVEIROS DE CASTRO, Eduardo. Individuo e sociedade no Alto Xingu: os Yawalapiti. Dissertação (inédita) de Mestrado em Antropologia Social, Museu Nacional/Universidade Federal do Rio de Janeiro, 1977.

VIVEIROS DE CASTRO, Eduardo. A fabricação do corpo na sociedade xinguana. Boletim do Museu Nacional, Rio de Janeiro, 32, 1979. p.40-49.

VIVEIROS DE CASTRO, EDUARDO. Araweté: os deuses canibais. Rio de Janeiro: Zahar, 1986.

VIVEIROS DE CASTRO, Eduardo. Esboço de cosmologia Yawalapíti. In: VIVEIROS DE CASTRO, E. $A$ inconstância da alma selvagem e outros ensaios de antropologia. São Paulo: Cosac \& Naify, 2002. p. 25-85. 


\section{artes da vida}


